\title{
Purine Catabolism in Fusarium moniliforme
}

\author{
By A. M. ALLAM AND TAHANY A. ELZAINY \\ Laboratory of Microbial Chemistry, National Research Centre, Cairo, Egypt
}

(Accepted for publication I July 1970)

\section{SUMMARY}

Fusarium moniliforme utilized the purines hypoxanthine, xanthine and uric acid as sole nitrogen sources. Allantoin and urea supported relatively more growth. The methylated purines caffeine and theobromine were not utilized. Uric acid, allantoic acid, glyoxylic acid and ammonia were detected in culture filtrates. Xanthine dehydrogenase, uricase, allantoinase, allantoicase and urease were present in cell homogenates and cell-free extracts. Uric acid was degraded to allantoic acid via allantoin.

\section{INTRODUCTION}

Penicillium chrysogenum can utilize several purines as sole sources of nitrogen (Allam \& Elzainy, I969a). Cell-free extracts contained xanthine dehydrogenase, uricase, allantoinase, allantoicase and urease. Uric acid was degraded to allantoic acid by way of allantoin, and allantoin was degraded to glyoxylic acid via allantoic acid. These results indicated that purine breakdown by this fungus is similar to that shown in aerobic bacteria (Campbell, 1955; Franke \& Hahn, 1955). In the present work the pattern of purine catabolism was investigated in another fungus, Fusarium moniliforme. A preliminary report of this work has appeared (Allam \& Elzainy, I $969 b)$.

\section{METHODS}

\section{Cultures and preparation of cell-free extracts}

A local strain of Fusarium moniliforme, no. 13, was obtained from the National Research Centre of Egypt. Surface cultures of the organism were used and were prepared as previously described (Allam \& Elzainy, 1969a). After 3 days incubation at $30^{\circ}$, the mycelium was harvested and cell-free extracts prepared as described by Allam \& Elzainy (1969a).

Cell-homogenates. The freshly harvested mycelium was homogenized with $0 \cdot 1 \mathrm{M}$ potassium phosphate buffer, $\mathrm{pH} 7 \cdot 0$, for $5 \mathrm{~min}$. in a cold Waring blender.

Potassium allantoate. This was prepared by the alkaline hydrolysis of allantoin by the method of Young \& Conway (I942).

Chemical methods. Xanthine was determined by the method used by Litwack, Bothwell, Williams \& Elvehjem (1953); uric acid by the method of Blauch \& Koch (1939); allantoin, allantoic acid and glyoxylic acid by the method used by Franke, Taha \& Krieg (I952); ammonia by Nessler's reagent or by vaccuum distillation (Varner, Bullen, Vanecko \& Burrell, 1953); and protein by the method of Sutherland, Cori, Haynes \& Olsen (I949). 
Enzymatic assays. Xanthine dehydrogenase was assayed by conventional manometric techniques with air as the gas phase; uricase by the same techniques and by measuring the disappearance of uric acid and the formation of allantoin; allantoinase, allantoicase and urease as described in a previous publication (Allam \& Elzainy, $1969 a$ ).

Chromatography. Allantoin and allantoic acid were identified by paper chromatography as previously described (Allam \& Elzainy, I969a).

\section{RESULTS}

Growth of Fusarium moniliforme on different purines and other nitrogenous compounds

As shown in Table I, Fusarium moniliforme can grow on the chemically defined Czapek-Dox medium in which hypoxanthine, xanthine or uric acid replaced $\mathrm{NaNO}_{3}$ as sole source of nitrogen. The growth on xanthine or uric acid was approximately equal to that obtained on $\mathrm{NaNO}_{3}$. However, no growth was obtained with the methylated purines caffeine and theobromine. Similar results were reported by Allam \& Elzainy (I969a) and by Kim \& Wolf (I96I) using Penicillium chrysogenum. Table I also shows that allantoin and urea supported slightly better growth than that on hypoanthine, xanthine or uric acid. The poor growth with $\mathrm{NH}_{4} \mathrm{Cl}$ may be due to the fall in $\mathrm{pH}$ value following ammonium uptake.

\section{Table I. Growth of Fusarium moniliforme on different purines and other nitrogenous compounds} Triplicate culture flasks contained $50 \mathrm{ml}$. of Czapek-Dox medium in which $\mathrm{NaNO}_{3}$ was
replaced by a nitrogen-equivalent amount of each $\mathrm{N}$ source, and were incubated 8 days at $28^{\circ}$.

$\begin{array}{lc}\text { Nitrogen source } & \begin{array}{c}\text { Mean mycelial } \\ \text { dry wt } \\ \text { (mg./flask) }\end{array} \\ \text { Hypoxanthine } & 210 \cdot 0 \\ \text { Xanthine } & 271 \cdot 9 \\ \text { Uric acid } & 242 \cdot 6 \\ \text { Caffeine } & 0 \cdot 0 \\ \text { Theobromine } & 0 \cdot 0 \\ \text { Allantoin } & 284 \cdot \mathrm{I} \\ \text { Urea } & 295 \cdot 5 \\ \mathrm{NaNO}_{3} & 266 \cdot \mathrm{I} \\ \mathrm{NH}_{4} \mathrm{Cl} & 143 \cdot 0\end{array}$

Detection of some intermediates in the media during growth on xanthine

Table 2 shows the occurrence of uric acid, allantoic acid, glyoxylic acid and ammonia in the media in which xanthine served as sole $\mathbf{N}$ source. Allantoin and urea could not be detected; the rate of their utilization may have equalled the rate of their formation, since cell-free extracts of this organism contain fairly active allantoinase and urease. Glyoxylic acid could be derived either from the purine or from the sugar of the medium. In subsequent experiments, extracts of Fusarium moniliforme were found to exhibit a weak allantoicase activity, suggesting that at least part of the glyoxylic acid might be formed from the purine. Similar results were reported by Sukhenko \& Podgainaya (1958), who studied the utilization of uric acid by Microsporum lanosum, M. ferrugineum and Fusarium sp. 
Xanthine dehydrogenase and uricase in cell homogenates

Figure $\mathrm{r}$ shows xanthine dehydrogenase and uricase activities in cell homogenates of Fusarium moniliforme grown with xanthine as sole source of nitrogen. Oxidation rates were very similar. Also the homogenates clearly had a fairly high endogenous rate of oxygen uptake, about $50 \%$ of that when either xanthine or uric acid was added to the reaction mixture, as estimated after $3 \frac{1}{2} \mathrm{~h}$. Similar results were reported by Taha, Krieg \& Franke (I955), who studied the oxidation of xanthine and uric acid in several fungal species.

Table 2. The occurrence of intermediary metabolites during the utilization of xanthine

Pooled samples from triplicate culture flasks were analysed; each flask contained $50 \mathrm{ml}$. of the medium in which $48.6 \mathrm{mg}$. of xanthine replaced $\mathrm{NaNO}_{3}$. Values are in mg./culture flask.

$\begin{array}{cccccc}\begin{array}{c}\text { Time in } \\ \text { days }\end{array} & \text { Xanthine } & \begin{array}{c}\text { Uric } \\ \text { acid }\end{array} & \begin{array}{c}\text { Allantoic } \\ \text { acid }\end{array} & \begin{array}{c}\text { Glyoxylic } \\ \text { acid }\end{array} & \mathrm{NH}_{3} \\ 2 & 26.70 & 4.70 & 0.08 & 0.09 & 0.466 \\ 4 & 12.40 & 3.00 & 0.08 & 0.18 & 0.232 \\ 6 & 3.30 & 1.06 & 0.15 & 0.12 & 0.216 \\ 8 & 1.16 & 0.13 & 0.04 & 0.16 & 0.186\end{array}$

\section{Uricase and combined uricase-allantoinase activities}

In this experiment $7 \cdot 2 \mu$ moles of uric acid were incubated with $16 \mathrm{mg}$. of extract protein of xanthine-grown mycelia in the presence of $90 \mu$ moles of sodium pyrophosphate buffer, $\mathrm{pH} 8 \cdot 6$. This reaction mixture $\left(4 \mathrm{ml}\right.$.) was incubated at $37^{\circ}$ for $4 \mathrm{~h}$. Uric acid disappearance and allantoin and allantoic acid formation were followed. One-half of the uric acid disappeared in the first $65 \mathrm{~min}$. and almost all of it after $150 \mathrm{~min}$. Analysis of the reaction mixture at the end of the incubation period showed the formation of $4.6 \mu$ moles of allantoin and 3.0 moles of allantoic acid. However, glyoxylic acid was not detected in this reaction mixture. The formation of allantoic acid indicates the presence of allantoinase which hydrolysed part of the allantoin formed to allantoic acid. Allantoin therefore appears to be an intermediate in the degradation of uric acid to allantoic acid. Comparable results were reported by Allam \& Elzainy (1969a) using extracts of Penicillium chrysogenum.

\section{Allantoinase, allantoicase and urease activities}

The enzyme allantoinase was demonstrated in extracts of xanthine-grown mycelia by following the formation of allantoic acid when allantoin was incubated with these extracts at $37^{\circ}$. The reaction mixture $(4 \mathrm{ml}$.) contained $34 \mu$ moles of allantoin, $6.6 \mathrm{mg}$ of extract protein, and $100 \mu$ moles of potassium phosphate buffer, $\mathrm{pH} 7 \cdot 0$. Over the first $\mathrm{I} 5 \mathrm{~min}$. allantoic acid was produced at the rate of $\mathrm{I} 3 \pm \mathrm{I} \mu \mathrm{mole} / \mathrm{h}$.

Table 3 shows the low allantoicase activity found in these extracts. No activity was obtained in the absence of neutral phenylhydrazine. This allantoicase activity is considerably weaker than that demonstrated in Penicillium chrysogenum, for which the addition of phenylhydrazine was not required.

Urease activity in the same extracts was determined by following the formation of ammonia when $60 \mu$ moles of urea were incubated at $37^{\circ}$ with $6.6 \mathrm{mg}$. of extract pro- 
tein in the presence of $100 \mu$ moles of potassium phosphate buffer, $\mathrm{pH} 7 \cdot 0$ (total volume $3 \mathrm{ml}$.). The initial rate of ammonia formation was $170 \pm 10 \mu$ mole $/ \mathrm{h}$. Comparable urease activity was reported in extracts of Penicillium chrysogenum (Allam \& Elzainy, I969a). The presence of an active urease points to the important role of this enzyme: it seems that any urea formed as a result of the serial degradation of the purine skeleton, acting as the sole source of nitrogen, is rapidly hydrolysed to ammonia.

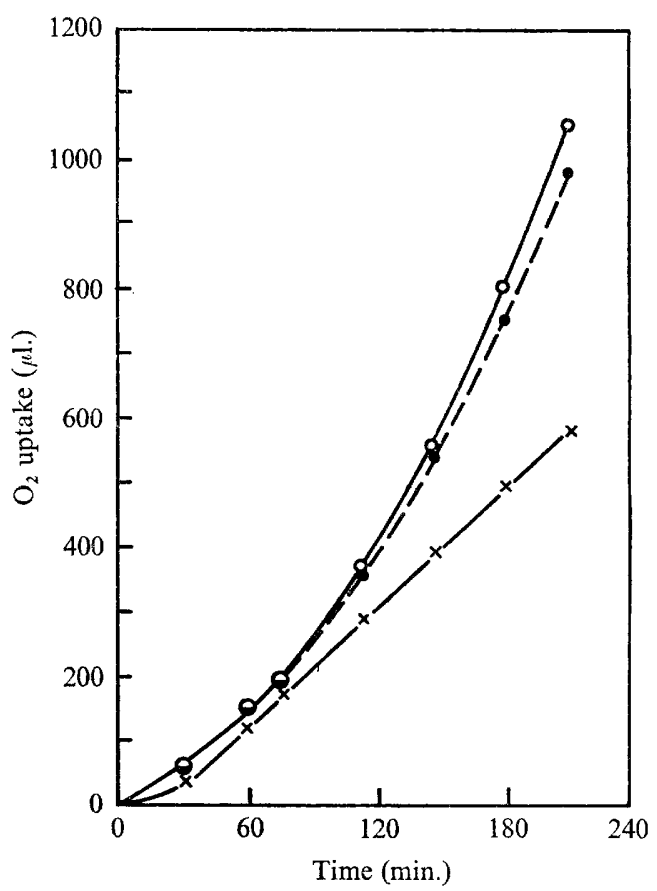

Fig. 1. Xanthine and uric acid oxidation by cell homogenates of Fusarium moniliforme grown with xanthine. Each manometric flask contained: xanthine or uric acid, as indicated, $40 \mu$ moles (side arm); potassium phosphate buffer ( $\mathrm{pH} 7 \cdot 0$ ), $100 \mu$ moles; cell homogenates, $\mathrm{I} \cdot 0 \mathrm{ml}$; $20 \% \mathrm{KOH}, 0.2 \mathrm{ml}$. (centre well); total volume, $3 \mathrm{ml}$; t temp. $30^{\circ}$. Othine; $\longrightarrow$, uric acid; $\times \longrightarrow$, endogenous.

Table 3. Allantoicase in extracts of Fusarium moniliforme

Reaction mixture contained: potassium allantoate, $32 \mu$ moles; potassium phosphate buffer (pH 7.4), $50 \mu$ moles; neutral phenylhydrazine, $30 \mu$ moles; extract, $5.94 \mathrm{mg}$. of protein; total volume, $3 \cdot 3 \mathrm{ml}$; t temp. $37^{\circ}$.

$\begin{array}{cc}\text { Time } & \begin{array}{c}\mu \text { moles } \\ \text { glyoxylic acid } \\ \text { formed }\end{array} \\ 0 & - \\ 30 & 0.2 \\ 55 & 0.55\end{array}$

\section{DISCUSSION}

The degradation of xanthine by this organism follows almost the sequence reported for Penicillium chrysogenum (Allam \& Elzainy, 1969a), involving the oxidation of 
xanthine to uric acid. The latter is then converted to allantoic acid via allantoin. Allantoic acid is in turn degraded to glyoxylic acid and urea. Urea is finally hydrolysed to ammonia and $\mathrm{CO}_{2}$.

The principal difference between the enzymes of Fusarium moniliforme and those of Penicillium chrysogenum is the comparatively low allantoicase activity of the former organism, which may be interpreted on the basis of the equilibrium of the reaction being in favour of allantoate formation. Trijbels \& Vogels (1967) reported that the reaction catalysed by allantoicase is reversible in Pseudomonas aeruginosa. It is also possible that allantoate is degraded via more than one pathway in F. moniliforme.

Sincere appreciation is expressed for the facilities offered by the National Research Centre, Cairo, Egypt, which enabled the authors to accomplish this work.

\section{REFERENCES}

Allam, A. M. \& Elzainy, T. A. (I969a). Degradation of xanthine by Penicillium chrysogenum. Journal of General Microbiology 56, 293.

Allam, A. M. \& Elzainy, T. A. (1969b). Utilization and degradation of purines by Fusarium moniliforme. Arab Chemical Congress, p. II.

BLAUCH, M. B. \& KoCH, F. C. (1939). A new method for the determination of uric acid in blood with uricase. Journal of Biological Chemistry r3o, 443.

CAMPBELl, L. L. (1955). Oxidative degradation of uric acid by cell extracts of a Pseudomonas. Biochimica et Biophysica Acta 18, 160.

Franke, W. \& HahN, G. E. (1955). Untersuchungen zum bakteriellen Purinabbau. I. Über den Harnsäureabbau durch Pseudomonas aeruginosa. Zeitschrift für Physikalische Chemie 299, 15.

Franke, W., Taha, E. D. M. \& Krieg, L. (I952). Purinoxydierende Fermente aus Schimmelpilzen. Uber die Uricase der Schimmelpilze. Archiv für Mikrobiologie 17, 255.

KIM, Y. T. \& Wolf, F. T. (I96I). Utilization of nucleic acid derivatives by Penicillium chrysogenum. Bulletin of the Torrey Botanical Club. 88, 42.

Litwack, G., Bothwell, J. W., Williams, J. N. \& Elvehjem, C. A. (1953). A colorimetric assay for xanthine oxidase in rat liver homogenates. Journal of Biological Chemistry 200, 303.

SukHenko, F. T. \& Podgainaya, E. S. (1958). Uric acid transformation by some fungi. Biokhimiya 32, 185 .

Sutherland, E. W., Cori, C. F., Haynes, R. \& Olsen, N. S. (1949). Purification of the hyperglycemicglycogenolytic factor from insulin and from gastric mucosa. Journal of Biological Chemistry $\mathbf{1 8 0}$, 825 .

Taha, E. D. M., Krieg, L. \& Franke, W. (I955). Purinoxydierende Fermente aus Schimmelpilzen. Über die Xanthindehydrase der Schimmelpilze. Archiv für Mikrobiologie 23, 67.

Trijbels, F. \& Vogels, G. D. (1967). Allantoate and ureidoglycollate degradation by Pseudomonas aeruginosa. Biochimica et Biophysica Acta $\mathbf{1 3 2}$, I 15.

VARner, J. E., Bullen, W. A., Vanecko, S. \& Burrell, R. C. (I953). Determination of ammonium, amide, nitrite and nitrate nitrogen in plant extracts. Analytical Chemistry 25, 1528.

Young, E. G. \& Conway, C. F. (1942). On the estimation of allantoin by the Rimini-Schryver reaction. Journal of Biological Chemistry 142, 839 . 